Article

\title{
One-Year Surveillance of the Chemical and Microbial Quality of Drinking Water Shuttled to the Eolian Islands
}

\author{
Antonio Proto ${ }^{1}$, Ilaria Zarrella ${ }^{1}$, Carmine Capacchione ${ }^{1}$ and Oriana Motta ${ }^{2, *}$ \\ 1 Department of Chemistry and Biology, University of Salerno, via Giovanni Paolo II 132, \\ Fisciano (SA) 84084, Italy; E-Mails: aproto@unisa.it (A.P.); ilaria.zarrella@gmail.com (I.Z.); \\ ccapacchione@unisa.it (C.C.) \\ 2 Department of Human, Philosophical and Educational Science, University of Salerno, \\ via Giovanni Paolo II 132, Fisciano (SA) 84084, Italy \\ * Author to whom correspondence should be addressed; E-Mail: omotta@unisa.it; \\ Tel.: +39-89-963-083.
}

Received: 8 October 2013; in revised form: 11 December 2013 / Accepted: 2 January 2014 / Published: 17 January 2014

\begin{abstract}
This work presents the chemical and biological characteristics of drinking water shuttled from the main land (Naples, Campania, Italy) to the Eolian islands (situated off the north-eastern coast of Sicily). The data obtained from a one year surveillance program, (January to December, 2012) indicate that the quality of the water delivered to the islands meets the drinking water quality standard year-round. During summer, when requests for drinking water increase with the increase of the islands population, the quality of the shipped water decreases, most likely due to the use of older vessels in addition to those used during the rest of the year. The results suggest an implementation of a monitoring program at the point-of-use in order to identify potential sources of contamination early in shipped drinking water and, therefore, to manage the potential risk of waterborne illness more effectively.
\end{abstract}

Keywords: shipped water; microbial and chemical contamination; public health

\section{Introduction}

A clean, constant supply of drinking water is essential to every human community. The possible sources of this commodity are ground or surface water, such as lakes, rivers and reservoirs. In some 
cases, these sources are close to the population; other times, drinking water suppliers get their water from sources many miles away. In the case of small islands where ground water is not only limited, but also does not meet drinking water standards, the removal of all contaminants and minerals would be extremely expensive. Therefore, in these cases, the preferred system is to shuttle drinking water by tankers. It is worth noting that in this case, drinking water that is not properly treated or disinfected or that travels through an improperly maintained distribution system may pose some health risks [1-4]. In order to avoid contamination, tankships need to be properly designed for the water trade. Likewise, the risk of waterborne-disease outbreaks mainly depends on the quality of water and on the maintenance of the tanker fleet.

It is well known that drinking water distribution systems are vulnerable to external contaminant entry if there is a loss of physical/hydraulic integrity. In their 2006 report on risk assessment and reduction for distribution systems, the Committee on Public Water Supply Distribution Systems of the National Research Council [5] defined a loss of physical integrity as when the system no longer acts as a barrier that prevents external contamination from deteriorating the internal drinking water supply. Associated pathways of contamination include water main breaks/repair sites, uncovered reservoirs or covered storage tanks with structural deficiencies, cross-connections with no, inappropriately installed or inadequately maintained backflow prevention devices and backflow or contaminant intrusion caused by low-pressure events [6].

The presence of contaminants in drinking water can result in both acute and chronic effects [7-10]. Acute effects occur within a few hours or days of the ingestion of high levels of contaminant and are mostly caused by human pathogens, such as viruses and bacteria. When high levels occur, they can cause illness and can be dangerous or deadly for those who are immune-compromised or vulnerable, like children or the elderly. The drinking water contaminants that can have chronic effects are chemicals, such as disinfection by-products, solvents and pesticides [11], and metals, such as arsenic [12-16].

Waterborne-disease outbreaks, associated with drinking water contaminated during shipping, are not easily detected. First, not all outbreaks are recognized, investigated or reported to health officials or local authorities. Second, the epidemiologic evidence must implicate water as the probable source of illness. However, in order to prevent waterborne outbreaks, the distribution system has to be frequently monitored for the early identification of a possible intrusion of contamination into the distribution system.

The current state of monitoring drinking water transport in Italy is regulated by Legislative Decree $31 / 2001$ [17], to provide good practices for shipping and to minimize the risk. In this paper, the physico-chemical and microbiological characteristics of the water delivered from the Italian main land (Campania) to the Eolian Islands (Sicily) are reported. Twenty vessels were monitored multiple times through a one year distribution before the transport of water. To our knowledge, this is the first study that reports the microbial and physico-chemical quality of water shuttled to a small island.

\section{Materials and Methods}

\subsection{Sample Collection}

Twenty vessels (twelve aged less than ten years and eight aged more than 30 years) were monitored for a single year before the transport of water. In Figure 1, a map of the distribution network is shown. 
Figure 1. Map of Italy (a) Zoom on the Eolian Islands (b); The transport route is represented by the arrow.

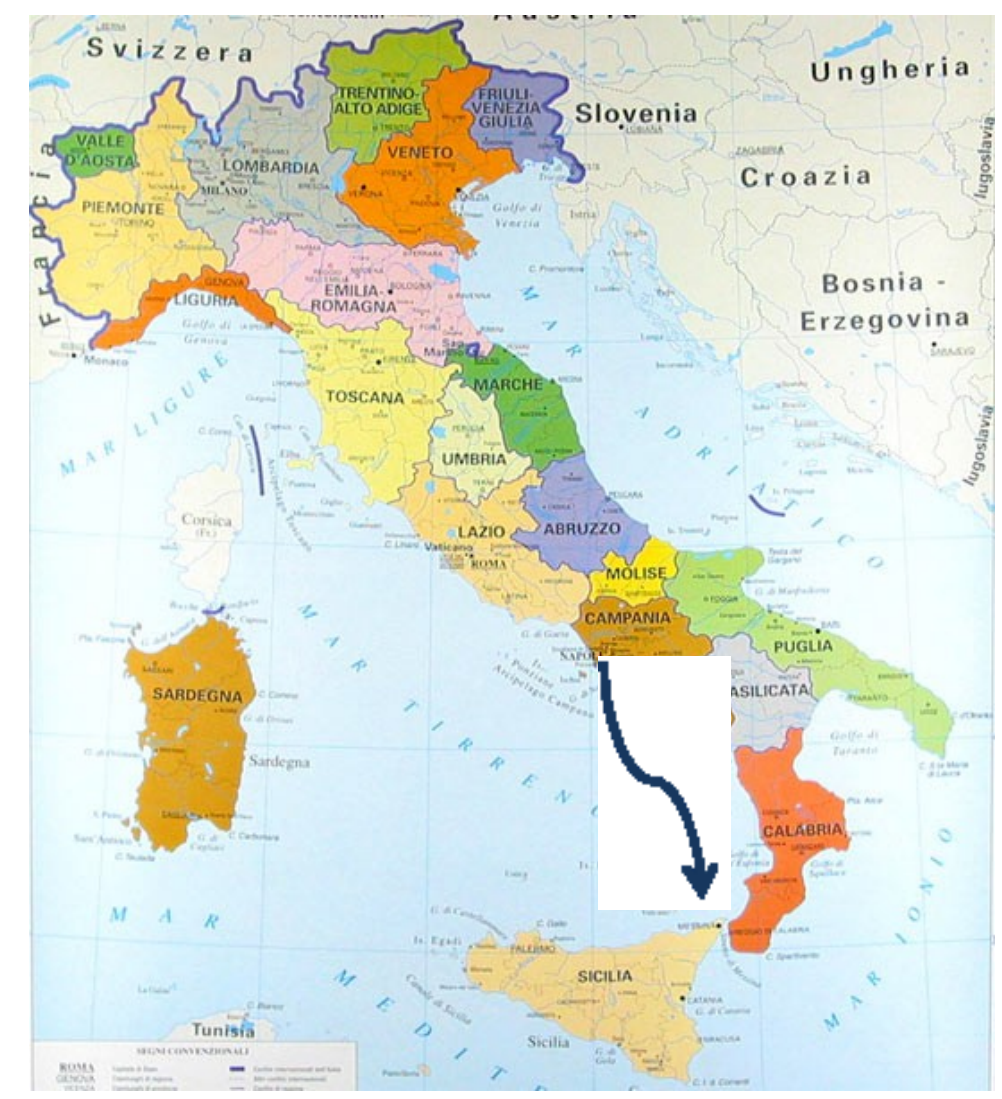

(a)

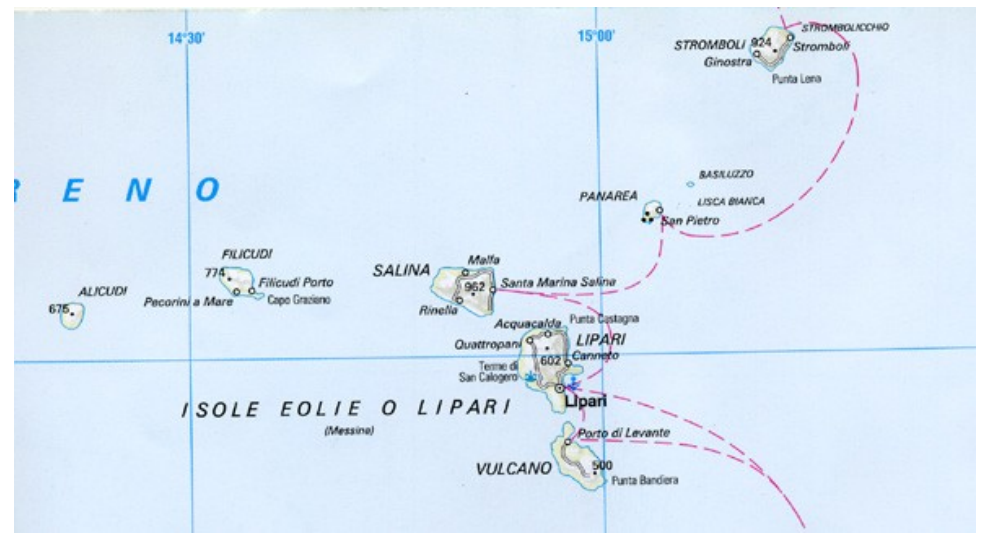

(b)

Microbiological determinations were conducted each time the vessels left from the port of Naples, where they get water, whereas for physical and chemical parameters, water samples were collected once a month on each vessel, during January and December 2012, using the sampling method No. 1030, published by APAT (Agenzia per la protezione dell'Ambiente e per i servizi tecnici) [18]. Water was sampled when it was already stored in the tanks of vessels immediately before transport. The samples were kept at $4{ }^{\circ} \mathrm{C}$, either in low-density polyethylene or Pyrex-glass containers, and were delivered to the laboratory within $4 \mathrm{~h}$. In total, 111 physico-chemical and 207 microbiological determinations were performed. For microbiological determination, the samples were collected in 
pre-sterilized glass bottles, containing sodium thiosulfate, and shipped on ice to the laboratory for analysis. Standard water-chemistry measurements and some physical properties, such as $\mathrm{pH}$, electrical conductivity and water temperature, were measured at the time of collection by means of a Hanna Instruments model HI 9625.

\subsection{Physico-Chemical Analyses}

Inorganic anions (bromates, chlorides, fluorides, nitrites and nitrates) were determined using a Dionex DX 120 ion chromatograph, equipped with an ion Pac AS14 column (4 mm $\times 250 \mathrm{~mm})$ and an ion Pac AG14 $(4 \mathrm{~mm} \times 50 \mathrm{~mm})$ guard column, and detected by suppressed conductivity. The eluent was $1.8 \mathrm{mM} \mathrm{Na}_{2} \mathrm{CO}_{3}: 1.6 \mathrm{mM} \mathrm{NaHCO}$ at a flow rate of $2 \mathrm{~mL} \mathrm{~min}^{-1}$ at a pressure of 970 psi. The quality control was ensured by analyzing blank samples and international standards.

Metallic cations (aluminum, arsenic, cadmium, chromium, copper, lead, iron, manganese and sodium) were determined by a Perkin Elmer model Analyst 100 atomic absorption spectrometer equipped with deuterium-arc background correction in acidic samples ( $\mathrm{pH}$ below 2.0).

The determination of benzene, epichlorohydrin and trihalomethanes (THMs) was performed on an HP 5890 Series II gas chromatograph equipped with an HP 5921A atomic emission detector and a capillary column (HP $62430 \mathrm{~m} \times 0.32 \mathrm{~mm}$ I.D. (internal diameter), $1.8 \mu \mathrm{m}$ film thickness).

\subsection{Microbiological Analyses}

Microbiological monitoring was conducted by analyzing some indicators of fecal pollution, since it has been demonstrated that the presence of pathogens in aquatic environments is intermittent, and their isolation is often complex, time-consuming and expensive [19-23]. Therefore, water samples were analyzed for heterotrophic plate count (HPC; number of colonies in $1 \mathrm{~mL}$ of sample) and for total Coliform, E. coli and Enterococcus (the number of colonies in $100 \mathrm{~mL}$ of the sample), following the procedure described in the APAT CNR-IRSA (Consiglio Nazionale delle Ricerche-Istituto di Ricerca sulle Acque) guidelines, volume 3 (microbiological methods).

\section{Results and Discussions}

Table 1 summarizes the chemical and physical results, as mean values, of the analysis. The table shows that the overall quality of the water is acceptable, the physical and chemical parameters being below the regulatory level. All the results obtained over the entire period of monitoring meet the standards, as reported for Legislative Decree 31/2001 [17].

It is worth noting that, due to the increasing request for drinking water from the islands during the summer, additional vessels were used from May to September. These tankships are older and/or not specifically built to transport drinking water. An additional eight vessels were added to the winter fleet (12 ships). The chemical and physical determination performed on these vessels, once a month, showed a deterioration of the overall water quality, as can be observed from Figures $2-4$, where a comparison of chloride content, conductivity and $\mathrm{pH}$ is reported. 
Table 1. Physical and chemical parameters relative to water samples collected in the tanks before shipping.

\begin{tabular}{|c|c|c|c|c|c|}
\hline Parameter & Method & Unit & Mean & SD & $\begin{array}{c}\text { Legislative } \\
\text { Decree 31/01 * }\end{array}$ \\
\hline Water Temperature & $\begin{array}{c}\text { APAT CNR-IRSA } \\
2100 \text { MAN 29/2003 }\end{array}$ & $\left({ }^{\circ} \mathrm{C}\right)$ & 13.2 & 0.8 & 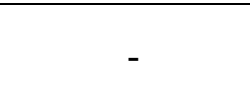 \\
\hline $\begin{array}{l}\text { Chemical Oxigen } \\
\text { Demand (COD) }\end{array}$ & ISS.BEB.027 REV 00 & $\left(\mathrm{mg} / \mathrm{L} \mathrm{O}_{2}\right)$ & 0.1 & 0.01 & 5.0 \\
\hline Electric Conductivity & $\begin{array}{c}\text { APAT CNR IRSA } \\
2030 \text { MAN 29/2003 }\end{array}$ & $(\mu \mathrm{S} / \mathrm{cm})$ & 812 & 342 & 2500 \\
\hline $\mathrm{pH}$ & $\begin{array}{c}\text { APAT CNR IRSA } \\
2060 \text { MAN 29/2003 }\end{array}$ & - & 7.9 & 0.2 & $6.5-9.5$ \\
\hline Total hardness & $\begin{array}{c}\text { APAT CNR IRSA } \\
2040 \text { MAN 29/2003 }\end{array}$ & $\left({ }^{\circ} \mathrm{F}\right)$ & 35.5 & 25.6 & $15-50$ \\
\hline Fixed residue at $180^{\circ} \mathrm{C}$ & ISS.BFA.032.REV 00 & $(\mathrm{mg} / \mathrm{L})$ & 350 & 35 & 1500 \\
\hline Ammonium & $\begin{array}{c}\text { APAT CNR IRSA } \\
4030 \text { MAN 29/2003 }\end{array}$ & $(\mathrm{mg} / \mathrm{L})$ & $<0.02$ & - & 0.50 \\
\hline Bromates & ISTISAN 03 & $(\mu \mathrm{g} / \mathrm{L})$ & $<1$ & - & 10 \\
\hline Chlorides & $\begin{array}{c}\text { APAT CNR IRSA } \\
4020 \text { MAN 29/2003 }\end{array}$ & $(\mathrm{mg} / \mathrm{L})$ & 52.68 & 37 & 250 \\
\hline Fluorides & $\begin{array}{c}\text { APAT CNR-IRSA } \\
4020 \text { MAN 29/2003 }\end{array}$ & $(\mathrm{mg} / \mathrm{L})$ & 0.14 & 2.02 & 1.50 \\
\hline Nitrates & $\begin{array}{c}\text { APAT CNR IRSA } \\
4020 \text { MAN 29/2003 }\end{array}$ & $(\mathrm{mg} / \mathrm{L})$ & 10 & 2.2 & 50 \\
\hline Nitrites & $\begin{array}{c}\text { APAT CNR IRSA } \\
4020 \text { MAN 29/2003 }\end{array}$ & $(\mathrm{mg} / \mathrm{L})$ & $<0.02$ & - & 0.50 \\
\hline $\mathrm{Al}$ & $\begin{array}{c}\text { APAT CNR IRSA } \\
3050 \text { MAN 29/2003 }\end{array}$ & $(\mu \mathrm{g} / \mathrm{L})$ & 4 & 2.1 & 200 \\
\hline As & $\begin{array}{c}\text { APAT CNR IRSA } \\
3080 \text { MAN 29/2003 }\end{array}$ & $(\mu \mathrm{g} / \mathrm{L})$ & $<1$ & - & 10 \\
\hline $\mathrm{Cd}$ & $\begin{array}{c}\text { APAT CNR-IRSA } \\
3120 \text { MAN 29/2003 }\end{array}$ & $(\mu \mathrm{g} / \mathrm{L})$ & 2.2 & 0.3 & 5.0 \\
\hline $\mathrm{Cr}$ & $\begin{array}{c}\text { APAT CNR-IRSA } \\
3150 \text { MAN 29/2003 }\end{array}$ & $(\mu \mathrm{g} / \mathrm{L})$ & $<1$ & - & 50 \\
\hline $\mathrm{Cu}$ & $\begin{array}{c}\text { APAT CNR-IRSA } \\
3250 \text { MAN 29/2003 }\end{array}$ & $(\mathrm{mg} / \mathrm{L})$ & 0.01 & 0.8 & 1 \\
\hline $\mathrm{Fe}$ & $\begin{array}{c}\text { APAT CNR IRSA } \\
3160 \text { MAN 29/2003 }\end{array}$ & $(\mu \mathrm{g} / \mathrm{L})$ & 3 & 0.8 & 200 \\
\hline $\mathrm{Mn}$ & $\begin{array}{c}\text { APAT CNR IRSA } \\
3190 \text { MAN 29/2003 }\end{array}$ & $(\mu \mathrm{g} / \mathrm{L})$ & 1 & 0.1 & 50 \\
\hline $\mathrm{Na}$ & potentiometric & $(\mathrm{mg} / \mathrm{L})$ & 15 & 2.4 & 200 \\
\hline $\mathrm{Pb}$ & $\begin{array}{c}\text { APAT CNR-IRSA } \\
3230 \text { MAN 29/2003 }\end{array}$ & $(\mu \mathrm{g} / \mathrm{L})$ & $<1$ & - & 10 \\
\hline Benzene & EPA-S021B & $(\mu \mathrm{g} / \mathrm{L})$ & $<0.01$ & - & 1.0 \\
\hline Epichlorohydrin & EPA-S260 B/96 & $(\mu \mathrm{g} / \mathrm{L})$ & $<0.01$ & - & 0.1 \\
\hline THMs & EPA-S260 B/96 & $(\mu \mathrm{g} / \mathrm{L})$ & $<0.01$ & - & 30 \\
\hline
\end{tabular}


Figure 2 shows a comparison of the concentration of chloride ion in water samples collected from vessels aged more than thirty years and less than ten years. It can be observed that in the older vessels, the maximum concentration of chloride ion almost reaches the Maximum Contaminant Level $(250 \mathrm{mg} / \mathrm{L})$. The Maximum Contaminant Level is the maximum permissible level of a contaminant in water delivered to users of a public water system, to ensure safety and to provide high quality water. The chloride concentrations of the two experimental group vessels (more than 30 years and less than 10 years) are significantly different (Mann-Whitney test, $\mathrm{N} 1=61, \mathrm{~N} 2=61 ; p<0.001$ ).

Figure 2. Experimentally determined chloride concentration in vessels aged more than thirty years and less than ten years. The distribution is shown by a vertical box plot as the median (lines), 25th and 75th percentiles (boxes) and 90th and 10th percentiles (whiskers). Circles mark the outliers.

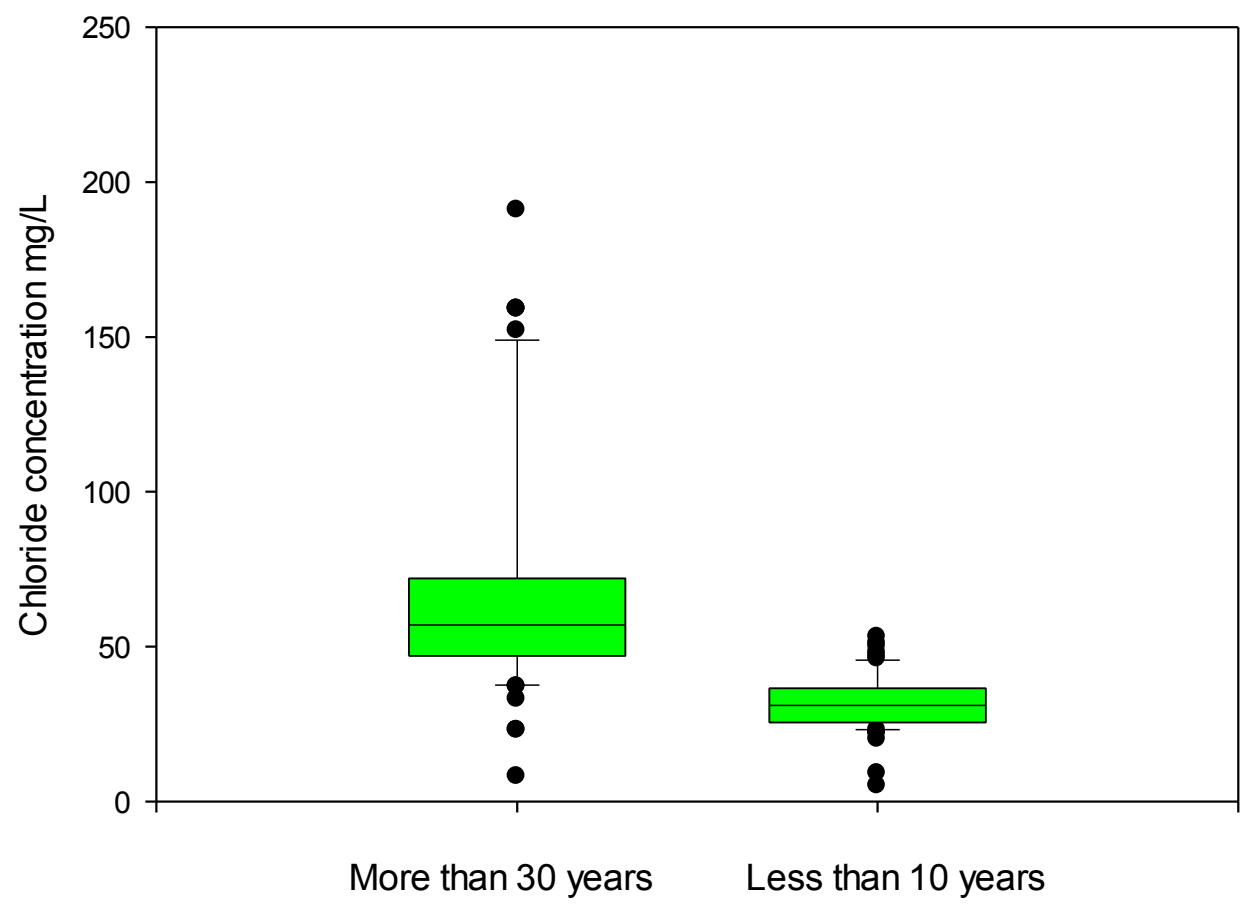

Different scenarios could explain the high levels of chloride ions. Firstly, one can suppose that water has been exposed to cracked, corroded or damaged tankers, secondly, that these latter have not been washed enough after being used to transport different liquids and, thirdly, that the tankers are not adequately sealed. This could allow the infiltration of marine water into the tanks and could reasonably also explain the higher conductivity values observed and the great variation of $\mathrm{pH}$ values.

As is shown in Figure 3, the conductivity values vary significantly between the two experimental groups (Mann-Whitney test, $\mathrm{N} 1=19, \mathrm{~N} 2=103, p=0.005$ ). The conductivity values are related to the higher concentration of chlorides that characterize the older vessels. The same trend was observed in the microbiological analysis, as will be discussed below.

The $\mathrm{pH}$ values measured in both types of vessels (more than 30 years old and less than 10 years old) were significantly different (Mann-Whitney test, N1 $=19, \mathrm{~N} 2=103, p=0.047$ ). 
Figure 3. Experimentally determined conductivities in vessels aged more than thirty years and less than ten years. The distribution is shown by a vertical box plot as the median (lines), 25th and 75th percentiles (boxes) and 90th and 10th percentiles (whiskers). Circles mark the outliers.

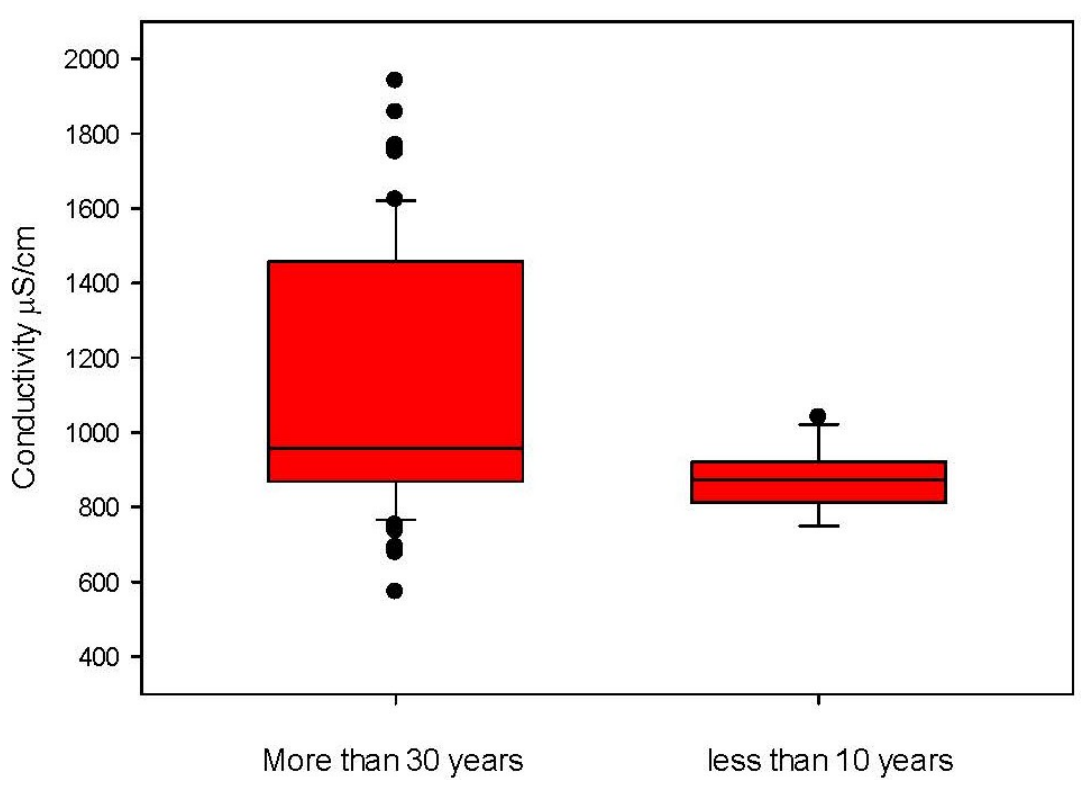

Figure 4. Experimentally determined $\mathrm{pH}$ values measured in vessel aged more than thirty years and less than ten years. The distribution is shown by a vertical box plot as the median (lines), 25th and 75th percentiles (boxes) and 90th and 10th percentiles (whiskers). Circles mark the outliers.

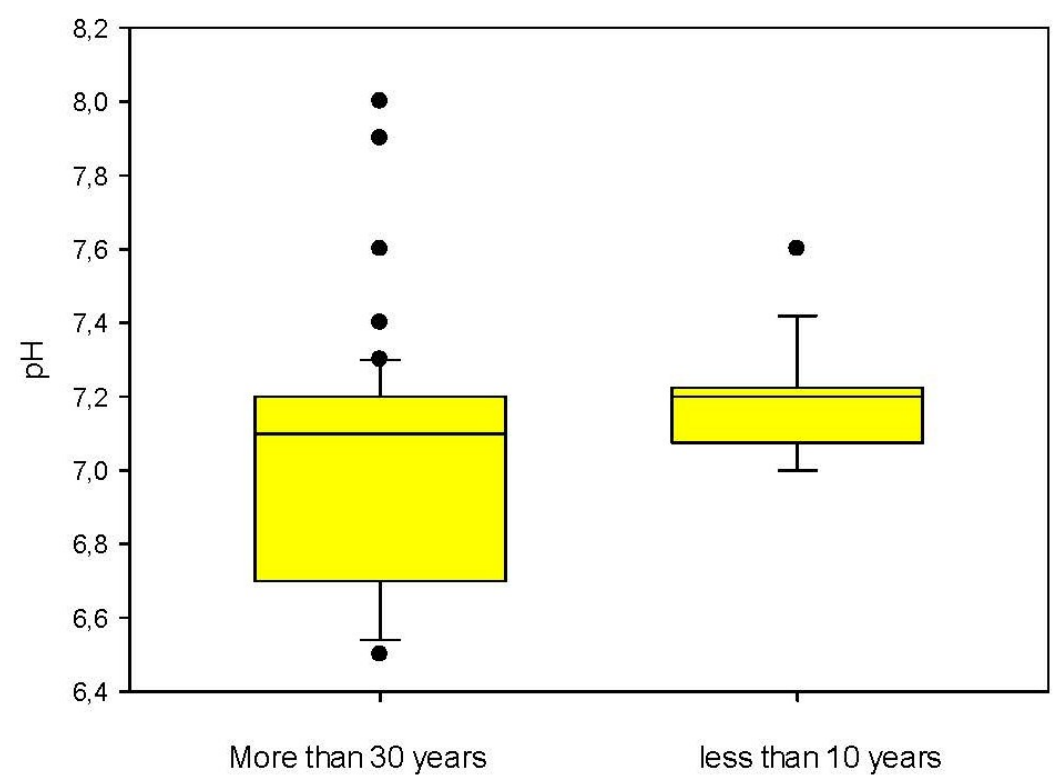

Figure 5 shows the results of the microbial analysis performed on all the vessels used to deliver drinking water to the Eolian Islands, during one year shipping, each time the vessels starts its transport. Total and fecal Coliform bacteria were always below the detection limit, thus excluding human health risk. During each month, the absence of E. coli, Coliform and Enterococcus was observed, except in July, when one of the old vessels showed a weak contamination of Coliform and Enterococcus, always 
below the accepted limits (about three cells/100 mL of water). Regarding the heterotrophic plate count (HPC), which is an indicator of general water quality within a distribution system [24], the levels are rather low. A great variation from the mean value, a great difference between minimum and maximum, is only observed during the months of June and July, and the highest average values were in August, which correspond to the period of the major request for drinking water and, then, to the use of older vessels, sometimes improperly utilized for drinking water transport in addition to those regularly used during the year. To analyze the differences in the number of bacteria identified in the water in the 12 months, we used a Kruskal-Wallis One Way Analysis of Variance on Ranks. The results confirmed that there are significant differences among the months $\left(\mathrm{H}_{(11)}=266.176 ; p<0.001\right)$. For the pairwise comparisons, Dunn's method has been used. It suggests that the HPC values measured in the vessels during August are significantly different from the other values measured during all other months $(p<0.05)$.

Therefore, though shipped water meets state standards and is generally safe to drink year-round, the potential threats to safe drinking water increase in the summer season.

Figure 5. Heterotrophic plate count (HPC) bacteria measured at temperature $\mathrm{T}=22^{\circ} \mathrm{C}$ during one year of monitoring of all the ships used to deliver drinking water from Naples to the Eolian Islands. The distribution is shown by the vertical box plot as the median (lines), 25th and 75th percentiles (boxes) and 90th and 10th percentiles (whiskers). Circles mark the outliers.
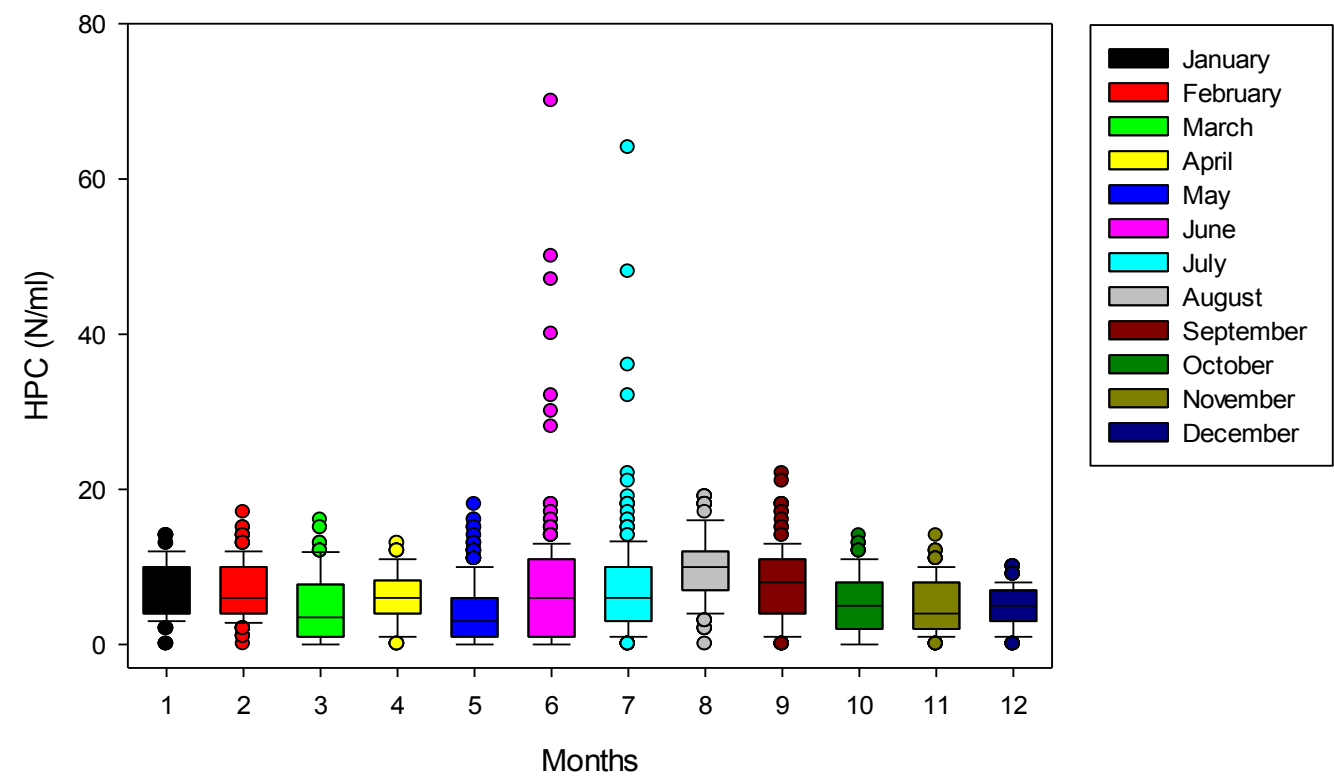

One more critical point that could add risk is the procedure adopted to deliver water from the ship to the island. Figure 6 is a picture of a vessel taken during the operation of water distribution at Filicudi, one of the Eolian Islands. It shows how water is transported through pipes partially immerged in sea water and/or lying on the harbor platform. These pipes are handled without detailed operating procedures, thereby producing potential for the ingress of contaminants. A greater level of cleanliness and hygiene should be adopted to mitigate these risks. 
Figure 6. Picture of a vessel taken during the operation of water distribution at Filicudi, one of the Eolian Islands.

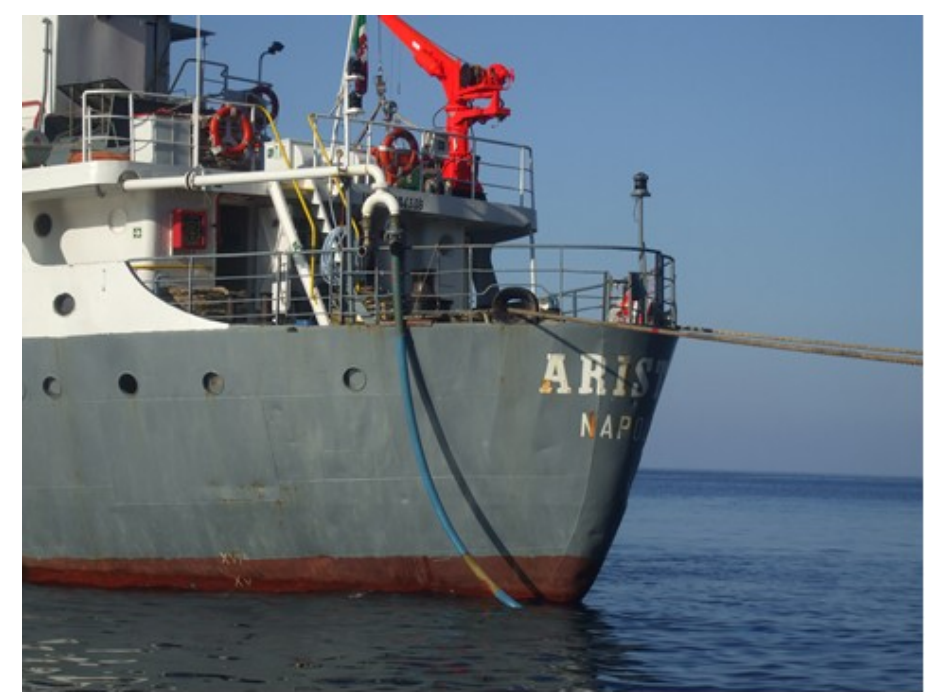

In this study, we did not evaluate any relation between water contamination after shipping and reported health concerns. However, we do provide some insight into the potential public health risks associated with the distribution systems from the main land to small islands. Nonetheless, we are convinced that a surveillance program would protect the imported drinking water and also assist in identifying system breakdowns, operator errors and other engineering-related activities that lead to outbreaks.

\section{Conclusions}

The results reported in this paper show that the drinking water quality is generally good; however, a systematic surveillance system is desirable to identify potential sources of contaminants in drinking water shipped to small islands early. Although monitoring does not necessarily suggest good operation conditions, it is crucial to ensure that clean and safe drinking water will be delivered to the islands. Water restrictions have demonstrated that the overall quality of drinking water changes, most probably due to the use of older vessels or vessels that are not specifically designed for water shipping. Since water contamination can occur during shipping and unloading, an implementation of the monitoring program at the point-of-use is suggested in order to identify potential sources of contamination in shipped drinking water early and, therefore, to manage the potential risk of waterborne illness more effectively.

\section{Acknowledgments}

This work was financially supported by Cleprin srl (Sessa Aurunca, CE) and by Fondi di Ateneo per la Ricerca di Base (FARB 2011), University of Salerno.

\section{Conflicts of Interest}

The authors declare no conflict of interest. 


\section{References}

1. Bates, A.J. Water as consumed and its impact on the consumer-Do we understand the variables? Food Chem. Toxicol. 2000, 38, S29-S36.

2. Leclerc, H.; Schwartzbrod, L.; Dei-Cas, E. Microbial agents associated with waterborne diseases. Crit. Rev. Microbiol. 2002, 28, 371-409.

3. Theron, J.; Cloete, T.E. Emerging waterborne infections: Contributing factors, agents, and detection tools. Crit. Rev. Microbiol. 2002, 28, 1-26.

4. Payment, P. Health Effects of Water Consumption and Water Quality. In Handbook of Water and Wastewater Microbiology; Academic Press: San Diego, CA, USA, 2003; pp. 209-219.

5. NRC (National Research Council). Drinking Water Distribution Systems: Assessing and Reducing Risks; The National Academies Press: Washington, DC, USA, 2006.

6. Kirmeyer, G.J.; Friedman, M.; Martel, K.; Howie, D.; LeChevallier, M.; Abbaszadegan, M.; Karim, M.; Funk, J.; Harbour, J. Pathogen Intrusion into the Distribution System; American Water Works Association Research Foundation: Denver, CO, USA, 2001.

7. Yoshida, T.; Yamauchi, H.; Sun, G.F. Chronic health effects in people exposed to arsenic via the drinking water: Dose-response relationships in review. Toxicol. Appl. Pharmacol. 2004, 198, 243-252.

8. De Roda Husman, A.M.; Bartram, J. Chapter 7 global supply of virus-safe drinking water. Perspect. Med. Virol. 2007, 17, 127-162.

9. Berger, P.S.; Clark, R.M.; Reasoner, D.J.; Rice, E.W.; Santo Domingo, J.W. (US EPA) Water, Drinking. In Encyclopedia of Microbiology, 3rd ed.; Elsevier Ltd.: San Diego, CA, USA, 2009; ISBN: 978-0-12-373944-5.

10. Iannece, P.; Motta, O.; Tedesco, R.; Carotenuto, M.; Proto, A. Determination of perchlorate in bottled water from Italy. Water 2013, 5, 767-779.

11. Bennett, G.F. Risk Assessment for Chemicals in Drinking Water; Howd, R.A., Fan, A.M., Eds.; Wiley Interscience, JohnWiley and Sons: Hoboken, NY, USA, 2008; ISBN: 978-0-471-72344-8.

12. Hall, M.; Chen, Y.; Ahsan, H.; Slavkovich, V.; van Geen, A.; Parvez, F.; Graziano, J. Blood arsenic as a biomarker of arsenic exposure: Results from a prospective study. Toxicology 2006, 225, 225-233.

13. Nriagu, J.O.; Bhattacharya, P.; Mukherjee, A.B.; Bundschuh, J.; Zevenhoven, R.; Loeppert, R.H. Arsenic in soil and groundwater: An overview. Trace Met. Contam. Environ. 2007, 9, 3-60.

14. Lindberg, A.L.; Rahman, M.; Persson, L.Å.; Vahter, M. The risk of arsenic induced skin lesions in Bangladeshi men and women is affected by arsenic metabolism and the age at first exposure. Toxicol. Appl. Pharmacol. 2008, 230, 9-16.

15. Kazia, T.G.; Araina, M.B.; Baiga, J.A.; Jamalia, M.K.; Afridia, H.I.; Jalbanib, N.T.; Sarfraza, R.A.; Qadir Shaha, A.; Niaza, A. The correlation of arsenic levels in drinking water with the biological samples of skin disorders. Sci. Total Environ. 2009, 407, 1019-1026.

16. Kwok, R.K. A review and rationale for studying the cardiovascular effects of drinking water arsenic in women of reproductive age. Toxicol. Appl. Pharmacol. 2007, 222, 344-350.

17. Attuazione della direttiva $98 / 83 / \mathrm{CE}$ relativa alla qualità delle acque destinate al consumo umano. Decreto Legislativo 2 febbraio 2001, No. 31. In Gazzetta Ufficiale, No. 52; Istituto Poligrafico e Zecca dello Stato S.p.A.: Roma, Italy, 3 March 2001. 
18. Belli, M.; Centioli, D.; de Zorzi, P.; Sansone, U.; Capri, S.; Pagnotta, R.; Pettine, M. Metodi analitici per le acque. In Manuali e Linee Guida dell'Agenzia per la Protezione dell'Ambiente e per i Servizi Tecnici (APAT), Rapporti 29/2993; I.G.E.R. srl: Roma, Italy, 2004.

19. Kay, D.; Fleisher, J.M.; Salmon, R.L.; Jones, F.; Wyer, M.; Godfree, A.; Zelenauch-Jacquotte, Z.; Shore, R. Predicting likelihood of gastroenteritis from sea bathing: Results from randomized exposure. Lancet 1994, 344, 904-909.

20. Bonde, G.J. Bacteriological methods for estimation of water pollution. Health Lab. Sci. 1966, 3, 124-128.

21. Pruss, A. Review of epidemiological studies on health effects from exposure to recreational water. Int. J. Epidemiol. 1998, 27, 1-9.

22. Elmund, G.K.; Allen, M.J.; Rice, E.W. Comparison of Escherichia coli, total coliform, and fecal coliform populations as indicators of wastewater treatment efficiency. Water Environ. Res. 1999, 71, 332-339.

23. US-Environmental Protection Agency. Bacterial Water Quality Standards for Recreational Waters (Freshwater and Marine Water); Office of Water: Washington, DC, USA, 2003.

24. World Health Organization. Heterotrophic Plate Counts and Drinking-water Safety: The Significance of HPCs for Water Quality and Human Health; Bartram, J., Cotruvo, J., Exner, M., Fricker, C., Glasmacher, A., Eds.; WHO: Geneva, Swedish; IWA Publishing: London, UK, 2003.

(C) 2014 by the authors; licensee MDPI, Basel, Switzerland. This article is an open access article distributed under the terms and conditions of the Creative Commons Attribution license (http://creativecommons.org/licenses/by/3.0/). 